\title{
Lipoprotein Binding to Cultured Human Hepatoma Cells
}

\author{
F. Krempler, G. M. Kostner, W. Friedl, B. Paulweber, H. Bauer, and F. Sandhofer \\ First Department of Medicine, Landeskrankenanstalten, A-5020 Salzburg, Austria; Institute of Medical Biochemistry, University of Graz, \\ Austria; and Institute of Molecular Biology, Austrian Academy of Science, A-5020 Salzburg, Austria
}

\begin{abstract}
Binding of various ${ }^{125} \mathrm{I}$-lipoproteins to hepatic receptors was studied on cultured human hepatoma cells (Hep G2). Chylomicrons, isolated from a chylothorax, chylomicron remnants, hypertriglyceridemic very low-density lipoproteins, normotriglyceridemic very low-density lipoproteins (NTG-VLDL), their remnants, low-density lipoproteins (LDL), and HDL-E (an Apo E-rich high-density lipoprotein isolated from the plasma of a patient with primary biliary cirrhosis) were bound by high-affinity receptors. Chylomicron remnants and HDL-E were bound with the highest affinity. The results, obtained from competitive binding experiments, are consistent with the existence of two distinct receptors on Hep G2 cells: (a) a remnant receptor capable of high-affinity binding of triglyceride-rich lipoproteins and HDLE, but not of Apo E free LDL, and (b) a LDL receptor capable of high-affinity binding of LDL, NTG-VLDL, and HDL-E. Specific binding of Apo E-free LDL was completely abolished in the presence of $3 \mathrm{mM}$ EDTA, indicating that binding to the LDL receptor is calcium dependent. Specific binding of chylomicron remnants was not inhibited by the presence of even $10 \mathrm{mM}$ EDTA. Preincubation of the Hep G2 cells in lipoprotein-containing medium resulted in complete suppression of LDL receptors but did not affect the remnant receptors. Hep G2 cells seem to be a suitable model for the study of hepatic receptors for lipoprotein in man.
\end{abstract}

\section{Introduction}

Because cholesterol ester deposition in the arterial wall is a major event in atheroma formation, much clinical interest has focused on cholesterol metabolism and its regulation. It is well-established that the liver plays a primary role in synthesis, secretion, and removal of cholesterol in the body (1-4). The mechanisms that regulate this central function of the liver in cholesterol metabolism, however, are not fully understood.

Cholesterol in the body is derived from two sources: exogenous cholesterol from intestinal absorption and endogenous cholesterol from synthesis in various tissues. In the vascular circulation cholesterol is transported and distributed between organs by four functionally different lipoprotein classes. Exogenous cholesterol is transported in chylomicrons, endogenous cholesterol is transported in very low-density lipoproteins (VLDL), ${ }^{1}$

Received for publication 18 November 1986.

1. Abbreviations used in this paper: Apo B, apolipoprotein B; Apo E, apolipoprotein $\mathrm{E} ; B_{\max }$, maximum binding capacity; HDL, high-density lipoprotein; HTG-VLDL, hypertriglyceridemic very low-density lipo-

J. Clin. Invest.

(c) The American Society for Clinical Investigation, Inc.

0021-9738/87/08/0401/08 $\$ 2.00$

Volume 80, August 1987, 401-408 low-density lipoproteins (LDL), and high-density lipoproteins (HDL).

These lipoproteins not only transport cholesterol in the blood stream but also play an important role in the regulation of cholesterol metabolism. This regulator function is mediated by the interaction of some apolipoproteins with specific receptors on the cell surface in various tissues (5-9). When cholesterol is taken up by these cells, the number of receptors is down-regulated, and cholesterol synthesis within the cells is suppressed (10).

A receptor for LDL was first described in cultured human fibroblasts (5). This receptor recognizes LDL by its apolipoprotein B (Apo B) moiety, but also binds apolipoprotein E (Apo E) containing HDL with high affinity (11). Therefore, these LDL receptors were also termed "Apo B,E receptors." LDL receptors, which have been demonstrated in many tissues $(5-8)$, mediate and regulate the uptake of endogenous cholesterol transported in LDL, the metabolic product of VLDL (12).

Whereas the LDL receptor of fibroblasts has been extensively investigated, fewer studies have been performed on the hepatic receptors for the various cholesterol-transporting lipoproteins. A number of studies investigated the uptake of lipoproteins by the liver. Liver perfusion experiments revealed an uptake of chylomicrons and chylomicron remnants (13-15). From these studies it was suggested that the uptake of chylomicrons into liver cells is mediated by Apo E and that remnant particles are taken up more rapidly than native lipoproteins. In addition, high-affinity binding of chylomicrons, VLDL, and LDL could be demonstrated in studies with liver membranes from various animals $(9,16)$, humans $(17)$, and from studies performed with cultured liver cells (18).

There are several lines of evidence that liver cells express two distinct lipoprotein receptors. (a) Chylomicron remnant catabolism is not significantly altered in patients with type II familial hypercholesterolemia (19). (b) The uptake of chylomicron remnants into liver cells of Watanabe heritable hyperlipidemic rabbits (20) or in animals fed a high-cholesterol diet (21) was found to be nearly normal. Recently, the apo E receptor has been isolated from canine and human liver membranes (22).

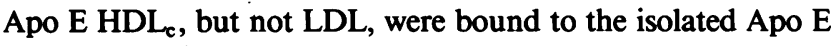
receptor. In summary, these studies indicate that one of the two distinct lipoprotein receptors on liver cell membranes preferentially binds chylomicron remnants, which are recognized by their apoprotein E moiety. This receptor was, therefore, designated as Apo E or chylomicron remnant receptor and does not interact with Apo B of LDL. The other receptor on liver cells was identified as LDL- or Apo B/E receptor, very similar to the LDL receptor of other tissues.

No agreement exists concerning the regulation of the receptors, the $\mathrm{Ca}^{2+}$ dependency of the binding, and the specificity of

protein; IEF, isoelectric focusing; LDL, low-density lipoprotein; LPDS, lipoprotein-deficient fetal calf serum; MEM, minimal essential medium; NTG-VLDL, normotriglyceridemic very low-density lipoprotein; VLDL, very low-density lipoprotein. 
the binding of various lipoproteins to human liver cells. In a number of studies it was found that the LDL receptor can be down-regulated by preincubation with lipoproteins $(17,18,23-$ 25 ), in other studies only a partial down-regulation could be observed $(26,27)$. The regulation of the $E$ receptor is also not fully understood. The expression of the $E$ receptor seems not to be affected by procedures that influence the activity of the $B / E$ receptor as cholesterol feeding or infusion of lipoproteins or bile acids $(9,16,28,29)$. These observations suggest, that the $E$ receptor seems not to be under metabolic control. Liver membranes obtained from patients with familial hypercholesterolemia, however, showed better binding of Apo E-containing lipoproteins after portocaval shunt surgery (17). Studies investigating the requirement for $\mathrm{Ca}^{2+}$ for the binding of lipoproteins to the $E$ - and $B / E$ receptors of liver cells reveal contradictory results $(9,23,24,30-34)$.

Furthermore, the specificity of the binding of lipoproteins of $d<1.063 \mathrm{~g} / \mathrm{ml}$ is not yet fully established. In particular, binding of VLDL particles has not been investigated in detail. The experiments presented in this paper were performed to study the binding of chylomicron remnants, VLDL, LDL, and an Apo E-rich particle named HDL-E to cultured human hepatoma cells (Hep G2) to assess the specificity of the binding of various lipoproteins and the regulation of the lipoprotein receptors.

\section{Methods}

\section{Isolation and labeling of lipoproteins}

Chylomicrons were isolated from a chylothorax. The effluent was substituted with $\mathrm{Na}_{2} \mathrm{EDTA}(1 \mathrm{mg} / \mathrm{ml})$ and $\mathrm{NaN}_{3}(1 \mathrm{mg} / \mathrm{ml})$ and then allowed to stand overnight at $4^{\circ} \mathrm{C}$. The floated chylomicrons were collected and washed six times in $0.15 \mathrm{M} \mathrm{NaCl}$ at $15,000 \mathrm{rpm}$ for $30 \mathrm{~min}$ in a Beckman SW 28 rotor (Beckman Instruments, Inc., Fullerton, CA). The last centrifugation was performed without EDTA and $\mathrm{NaN}_{3}$.

Chylomicron remnants. Chylomicrons were suspended in $0.15 \mathrm{M}$ $\mathrm{NaCl}(0.1 \mathrm{M}$ Tris-HCl, $\mathrm{pH} 8.5)$ to a final triglyceride concentration of $20 \mathrm{~g} /$ liter and then incubated with lipoprotein lipase in the presence of the $d 1.063 \mathrm{~g} / \mathrm{ml}$ infranatant of normal serum and in the presence of 50 $\mathrm{g}$ /liter fatty acid-free bovine serum albumin (BSA) at $37^{\circ} \mathrm{C}$ for $2 \mathrm{~h}$. Lipoprotein lipase was prepared from bovine milk (35). After the incubation chylomicron remnants were isolated by centrifugation at $d 1.019$ $\mathrm{g} / \mathrm{ml}$ at $22,000 \mathrm{rpm}$ for $18 \mathrm{~h}$ at $4^{\circ} \mathrm{C}$ in a 50.2 rotor (Beckman Instruments, Inc.).

Hypertriglyceridemic VLDL. Hypertriglyceridemic VLDL (HTGVLDL) were isolated from fasting serum of patients with marked hyperlipidemia with normal hepatic triglyceride lipase and lipoprotein lipase activity (36). None of them exhibited a $2 / 2$ Apo E phenotype as checked by isoelectric focusing (IEF) (37). HTG-VLDL were prepared by a modification of the method described by Gustafson et al. (38). A buffer solution of $d 1.006 \mathrm{~g} / \mathrm{ml}$ was layered over serum and then ultracentrifugation was performed at $80,000 \mathrm{~g}$ for $60 \mathrm{~min}$. HTG-VLDL were collected from the top layer by aspiration. In contrast to chylomicrons the Apo B moiety of these particles consisted of Apo B-100 as checked by sodium dodecyl sulfate-polyacrylamide gel electrophoresis (SDS-PAGE) on $3.75 \%$ gels (39).

HTG-VLDL remnants were prepared as described for chylomicron remnants.

Normotriglyceridemic VLDL (NTG-VLDL) were isolated from pooled serum of healthy volunteers by ultracentrifugation following standard procedures (40).

$V L D L$ remnants were prepared as described for chylomicron remnants.

Apo $E$-free $L D L$ were isolated from pooled fasting serum of healthy volunteers following a procedure recently published (41). Briefly, the lipoproteins of $d 1.006-1.063 \mathrm{~g} / \mathrm{ml}$ were prepared by ultracentrifugation in a fixed angle rotor and then washed and concentrated by density gradient ultracentrifugation. LDL prepared by this procedure were not free of Apo $E$ as checked by IEF and double immunodiffusion with monospecific antibodies against Apo $\mathrm{E}$. The LDL preparations isolated as described above were passed over an immune specific adsorber loaded with monospecific antibodies against Apo E. After immunoabsorption, the LDL were recentrifuged in the same density gradient as used for the isolation.

$H D L-E$ was isolated from plasma of a patient suffering from lecithin/ cholesterol acyltransferase (LCAT) deficiency caused by primary biliary cirrhosis. The patient had an LCAT activity of $<5 \%$ of normal control individuals (42). Plasma was obtained by plasmapheresis and passed over an anti-Apo B-containing column (43). In this step all Apo B containing VLDL and LDL were absorbed to the column. The density of the effluent, containing LP-X, HDL-E, and an abnormal HDL, was adjusted to $d 1.15 \mathrm{~g} / \mathrm{ml}$ and subjected to preparative ultracentrifugation $\left(145,000 \mathrm{~g}, 15^{\circ} \mathrm{C}, 24 \mathrm{~h}\right)$.

The floating lipoproteins were collected by tube slicing and recentrifuged in a linear $\mathrm{NaBr}$ gradient ranging from 1.030 to $1.080 \mathrm{~g} / \mathrm{ml}$ using a Beckman SW 41 rotor (Beckman Instruments, Inc.), 41,000 rpm, $15^{\circ} \mathrm{C}, 30 \mathrm{~h}$. The lipoproteins banding as a distinct fraction in the density region of $1.068 \mathrm{~g} / \mathrm{ml}$ were collected by aspiration with a hypodermic syringe and chromatographed over Bio-Gel A-1.5m, 200-400 mesh (100 $\times 1.2-\mathrm{cm}$ column) using a $0.15 \mathrm{M} \mathrm{NaCl} / 0.02 \mathrm{M}$ Tris- $\mathrm{HCl}$ buffer ( $\mathrm{pH}$ 7.8) which contained $\mathrm{i} \mathrm{mg} / \mathrm{ml} \mathrm{Na} \mathrm{EDTA}_{2}$ and $\mathrm{NaN}_{3}$. HDL-E eluted as a main fraction in a symmetrical peak at $45 \%$ of the column volume. This fraction was concentrated by Amicon ultrafiltration and stored for $<2$ wk under nitrogen in the dark and at $4^{\circ} \mathrm{C}$ before use. HDL-E behaved as a homogenous fraction by cellulose acetate and agarose gel electrophoresis and had the following chemical composition (wt/wt): protein, 32.5\%; phospholipids, 35.4\%; free cholesterol, 24.3\%; cholesterol ester, $6.7 \%$; triglyceride, $1.1 \%$. By electron microscopy using negative staining with phosphotungstate, HDL-E consisted mainly of flattened discs with a longer axis of $245 \AA$ and a shorter axis of $90 \AA$ with a few particles of spherical appearance. Immunochemically, HDL-E reacted with antibodies against apolipoproteins A I, A II, E, C, and albumin. The relative content of these proteins as determined from densitometric scanning of 12.5\% SDS-PAGE was: Apo E, 62\%; E-A II complex, 13\%; Apo A I, 9\%; albumin, 5\%; Apo C, 3\%; and unidentified bands $8 \%$.

Radioiodination of the lipoproteins was performed according to the method of McFarlane (44) as modified by Bilheimer et al. (45).

Cell culture. The human hepatoma cell line Hep G2 was obtained from Dr. B. B. Knowles, Wistar Institute for Anatomy and Biology, Philadelphia, PA. Stock cultures were maintained in minimal essential medium (MEM) supplemented with penicillin $(100 \mathrm{U} / \mathrm{ml})$, streptomycin $(1 \mu \mathrm{g} / \mathrm{ml})$, and $10 \%$ fetal calf serum (FCS) at $37^{\circ} \mathrm{C}$ in a humidified $95 \%$ air-5\% $\mathrm{CO}_{2}$ atmosphere. For binding experiments the cells were seeded in FB6-TC multi-dish trays. $48 \mathrm{~h}$ before the experiments, FCS was replaced by $10 \%$ lipoprotein-deficient FCS (LPDS) in the culture medium. Human skin fibroblasts were cultured as recently described (46).

Binding experiments. The cells were prechilled on crushed ice for 30 min. The medium was removed and the cells were incubated with various concentrations of radiolabeled lioproteins in MEM containing $25 \mathrm{mM}$ Hepes, $10 \%$ LPDS for $2 \mathrm{~h}$ at $4^{\circ} \mathrm{C}$. Nonspecific binding was determined by addition of a 50-fold, in some experiments a 100-fold excess of cold lipoproteins. To terminate the binding reaction, we removed the medium and washed the cells four times with ice-cold phosphate-buffered saline (PBS) containing $0.2 \%$ BSA and two additional times with PBS without albumin. The cells were then dissolved in $1 \mathrm{~N} \mathrm{NaOH}$ and transferred to counting vials for determination of the radioactivity. Specific binding was calculated by subtracting the nonspecific binding from total binding. In some experiments, $3 \mathrm{mM}$ or $10 \mathrm{mM} \mathrm{Na}_{2}$ EDTA was added to the medium instead of cold lipoproteins to measure $\mathrm{Ca}^{2+}$-dependent binding.

Calculation of the binding data. The binding data were plotted according to Scatchard (47). The binding parameters were calculated according to Munson and Rodbard (48) by a computer program. For control the binding data were also calculated from total binding as suggested by 
Mendel et al. (49). Both methods yielded practically identical results (Fig. 2, $B$ and $C$ ). Dissociation constants were expressed as micrograms apolipoprotein per milliliter medium and the maximum binding capacities were expressed as micrograms apolipoprotein bound per milligram of cell protein. Variation of protein content per dish within individual experiments was $9 \%$. The protein content between different experiments varied from 120 to $250 \mu \mathrm{g}$ per culture dish.

Chemical analyses. Protein concentrations were measured according to Lowry et al. (50). Total cholesterol was measured with the Liberman Burchard kit from Boehringer GmbH, Mannheim, FRG; triglycerides were estimated according to Eggstein and Kreutz (51).

SDS-PAGE was performed in 3.75 and $12.5 \%$ polyacrylamide gels containing $0.1 \%$ SDS, according to Laemmli (39). Electrophoresis was carried out with a constant voltage of $150 \mathrm{~V}$. The gels were stained in 0.2\% Coomassie Brilliant Blue G-250 (Serva Fine Biochemicals, Inc., Heidelberg, FRG). Apoprotein content of the chylomicrons, HTGLVLDL, and their remnants was estimated by radial immunodiffusion (Apo B, albumin) and electroimmunoassay (Apo E, Apo A I) after lyophilization and delipidation with diethyl ether. Apo C plus other apoproteins were calculated from the difference to the total apoprotein content as determined by Lowry et al. (50). The Apo B content of VLDL and their remnants was estimated by radial immunodiffusion without prior delipidation. Apo E, Apo A I, and albumin were measured from the TMU-soluble fraction of VLDL by electroimmunoassay. Apo C and the other apoproteins were calculated as described above.

\section{Materials}

Eagle's MEM and streptomycin were purchased from Gibco Bio-Cult, Glasgow, Scotland. Penicillin was a product of Biochemie, Kundl, Austria. FCS and trypsin EDTA solution were obtained from Seromed, Munich, FRG. Tissue culture flasks and plates were purchased from Falcon Plastics, Div. of BioQuest, Oxnard, CA. ${ }^{125}$ I-Sodium iodide was obtained from Radiochemical Centre, Amersham, England. Bio-Gel A-5m was obtained from Bio-Rad Laboratories, Richmond, CA, BSA from Sigma Chemical Co., St. Louis, MO.

\section{Results}

Chemical composition and apoprotein content of the lipoproteins is given in Table I. Chylomicrons showed a strong band in apo B-48 position on $3.75 \%$ SDS-PAGE (Fig. 1).

Lipoprotein binding to cultured human hepatoma cells. Highaffinity binding to cultured Hep G2 cells preincubated with LPDS was obtained with chylomicrons, chylomicron remnants, hypertriglyceridemic and normoglyceridemic VLDL, VLDL remnants, LDL, and HDL-E. Representative binding data are pre-

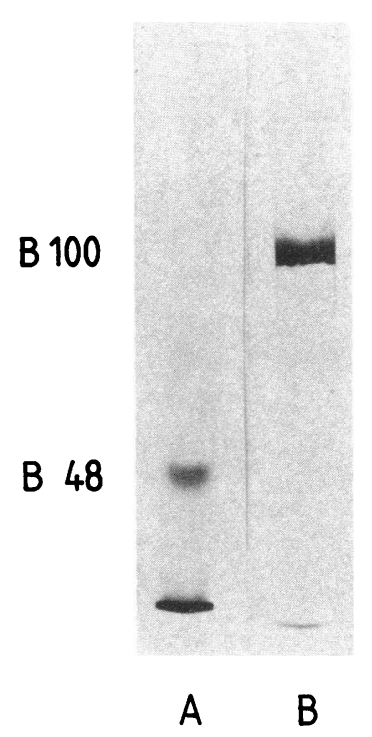

Figure 1. SDS-PAGE of Apo B from chylomicrons $(A)$ and VLDL $(B)$ performed on $3.75 \%$ gels. $\sim 100 \mu \mathrm{g}$ apoprotein was applied to each gel, and electrophoresis was performed as described in Methods.

sented in Figs. 2 and 3. The analysis of the specific binding by the method of Scatchard (47) yielded nonlinear plots for all of the tested lipoproteins (Figs. 2 and 3). The Scatchard plots could be resolved into a high-affinity component and a second component of extremely low affinity, presumably reflecting nonspecific binding. The calculation of the binding data from total binding or from specific binding yielded practically identical results as demonstrated in Fig. 2, $B$ and $C$. Values for dissociation constants $\left(K_{\mathrm{d}}\right)$ and maximum binding capacities $\left(B_{\max }\right)$, calculated from specific binding, are presented in Table II. Exact molecular weights cannot be given for triglyceride-rich lipoproteins, their remnants, and HDL-E. Therefore, the binding data were calculated on the basis of micrograms apoprotein. Because different apoproteins are responsible for the affinity of specific binding to the receptors, the concentrations of individual apoproteins are also given in Table II. Assuming that Apo E is responsible for the specific binding of triglyceride-rich lipoproteins to hepatic receptors, chylomicrons exhibited a higher affinity than VLDL. HTG-VLDL and NTG-VLDL were bound with a similar affinity. Chylomicron remnants were bound with a considerable higher affinity than native chylomicrons.

Only a minor difference in the binding affinity could be ob-

Table I. Chemical Composition of Lipoproteins

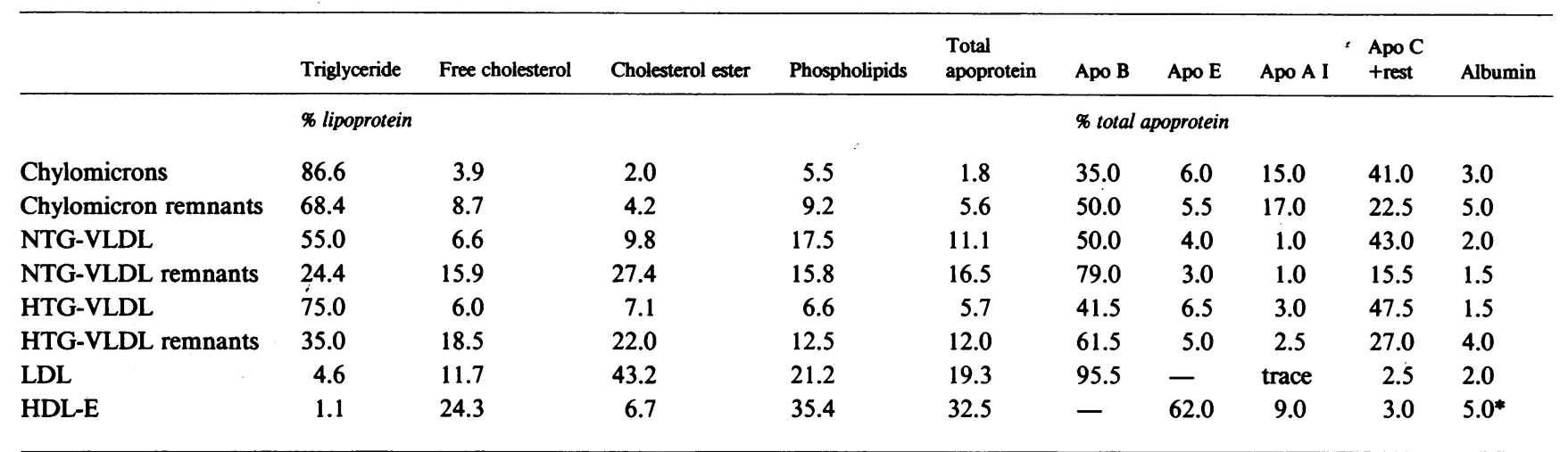

* In addition, HDL-E contained Apo E-A II complex (13.0\%) and unidentified proteins (8.0\%). 


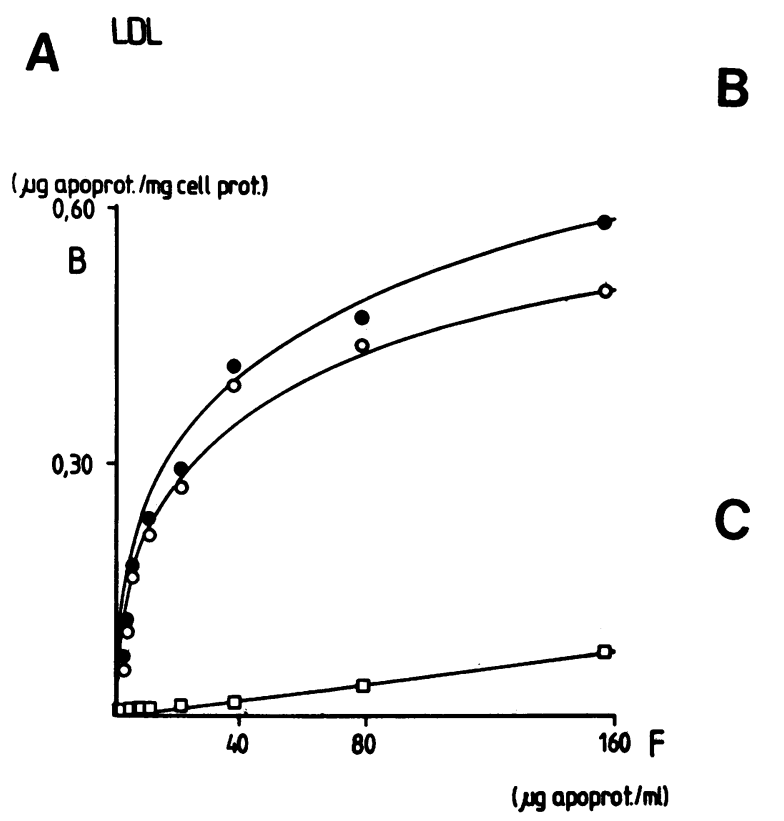

served for VLDL and their remnants. HDL-E was bound with an affinity comparable to that of chylomicron remnants. The binding sites for chylomicron remnants and HDL-E were remarkably low as compared with the other lipoproteins. It should be noted, however, that the data were calculated in micrograms apoprotein and not on molar basis.

Specific binding of LDL was completely abolished in the presence of 3 and $10 \mathrm{mM}$ EDTA. As a control the identical experiments were carried out with cultured human skin fibroblasts and the same result was obtained as with Hep G2 cells. In contrast to LDL, the specific binding of chylomicron remnants was not inhibited by the presence of 3 and 10 mM EDTA. In these experiments $\mathrm{Ca}^{2+}$ was removed from the incubation medium by EDTA. Theoretically, EDTA could interact with triglyceride-rich lipoproteins instead of with $\mathrm{Ca}^{2+}$. Thus, $\mathrm{Ca}^{2+}$ would be available for the binding simulating independence of receptor binding from $\mathrm{Ca}^{2+}$. Therefore, ${ }^{125} \mathrm{I}-\mathrm{LDL}$ binding experiments were performed in the presence of unlabeled chylomicron remnants and EDTA (data not shown). Binding of ${ }^{125} \mathrm{I}$ -
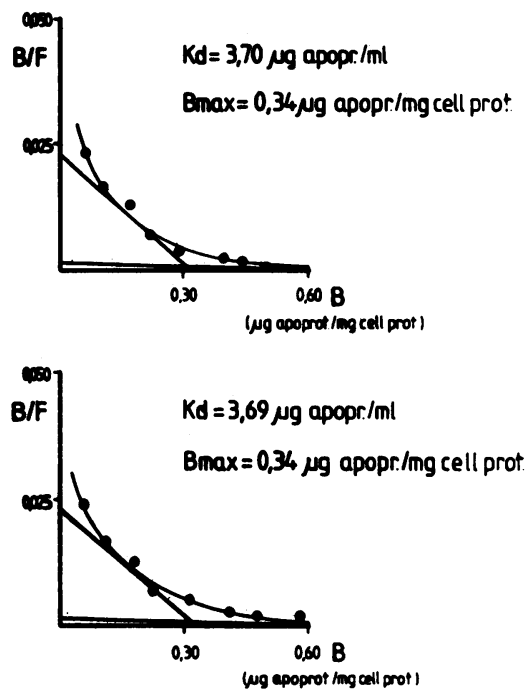

Figure 2. Total binding (๑), specific binding (o), and unspecific binding in the presence of 50-fold excess of unlabeled ligand $(\square)$ of ${ }^{125} \mathrm{I}-\mathrm{LDL}$ to Hep $\mathrm{G} 2$ cells $(A)$. Each point is the mean of triplicate dishes. B, ${ }^{125} \mathrm{I}-\mathrm{LDL}$ bound per milligram cell protein, $F$, concentration of ${ }^{125} \mathrm{I}-\mathrm{LDL}$ in the medium. Scatchard plots, calculated from specific binding $(B)$ and total binding $(C)$. B/ $F$, amount of bound lipoprotein divided by amount of unbound lipoprotein in incubation medium calculated in micrograms apolipoprotein. Nonlinear plots were resolved into high- and low-affinity components. Slopes of the two components are equal to $-1 / K_{d} ;$ the $x$-intercepts are the maximum amount of lipoprotein bound per dish.

LDL was inhibited, indicating that chylomicron remnants do not influence the effect of EDTA.

Specificity of binding. Competitive binding experiments were conducted to define the specificity of the two hepatic receptors. Binding of ${ }^{125}$ I-chylomicrons was inhibited by unlabeled native chylomicrons, native HTG-VLDL and NTG-VLDL, but not by LDL (Fig. 4). Binding of ${ }^{125}$ I-chylomicron remnants was inhibited by unlabeled chylomicron remnants and HDL-E, but not by LDL (Fig. 4). Binding of ${ }^{125}$ I-HTG-VLDL was not abolished by the addition of LDL (Fig. 5). Binding of ${ }^{125}$ I-NTG-VLDL, however, was inhibited to a considerable extent by LDL (Fig. 5). Binding of ${ }^{125} \mathrm{I}-\mathrm{LDL}$ was not inhibited by chylomicrons or HTG-VLDL, but was abolished by NTG-VLDL (Fig. 6). Binding of ${ }^{125} \mathrm{I}$-HDL-E was inhibited to a considerable extent by LDL (Fig. 6). The results of these experiments are consistent with the existence of two hepatic receptors, one responsible for the binding of chylomicrons, HTG-VLDL, and their remnants, and another responsible for the specific binding of LDL. NTG-VLDL and HDL-E are bound to both receptors.

\section{Chylomicrons}

$\mathrm{Kd}=2,80 \mathrm{\mu g}$ apopr./ml

Bmax $=0,25 \mu$ apopr./mg cell prot
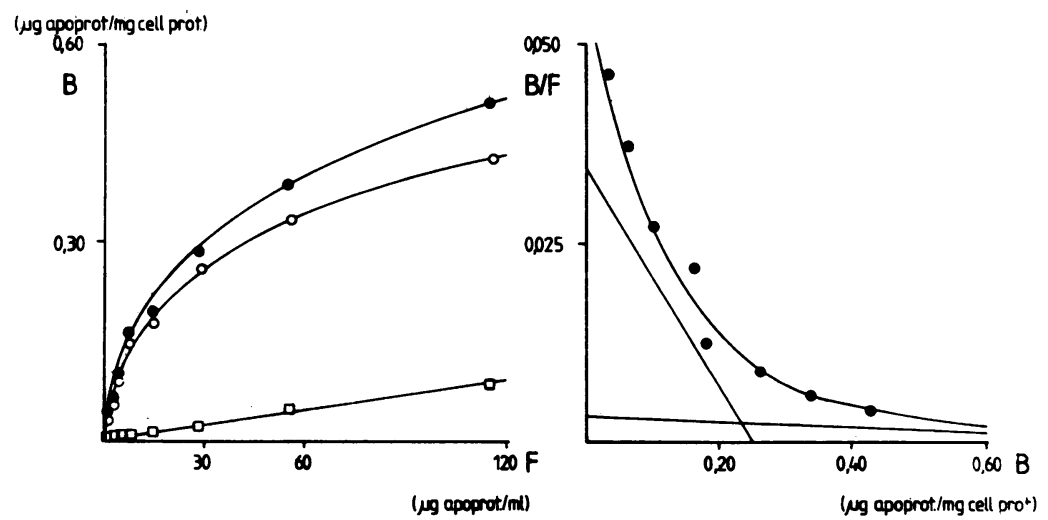

Figure 3. Total binding ( $(\bullet)$, specific binding (o), and unspecific binding in the presence of 50 -fold excess of unlabeled ligand $(\square)$ of ${ }^{125}$ I-chylomicrons to Hep G2 cells (left). Each point is the mean of triplicate dishes. B, ${ }^{125}$ I-chylomicrons bound per milligram cell protein. $\mathrm{F}$, concentration of ${ }^{125} \mathrm{I}$-chylomicrons in the medium. (Right) Scatchard plot calculated from specific binding. $B / F$, amount of bound lipoprotein divided by the amount of unbound lipoprotein in the incubation medium calculated in micrograms apolipoprotein. Nonlinear plots were resolved into high- and low-affinity components. Slopes of the two components are equal to $-1 / K_{\mathrm{d}}$; the $x$-intercepts are the maximum amount of lipoprotein bound per dish. 
Table II. Binding of ${ }^{125}$ I-Lipoproteins to Hep G2 Cells

\begin{tabular}{lllllll}
\hline & \multicolumn{1}{c}{$K_{\mathrm{d}}$} & & & & \\
\cline { 2 - 5 } & Total apoprotein & Apo B & Apo E & Apo C & $B_{\max }$ \\
\hline & $\mu g / m l$ & $\mu g / m l$ & $\mu g / m l$ & $\mu g / m l$ & $\mu g$ apoprotein/mg cell protein \\
Chylomicrons (4)* & $3.1(2.7-3.4)$ & 1.09 & 0.190 & 1.270 & $0.24(0.22-0.27)$ \\
Chylomicron remnants (4) & $0.4(0.28-0.60)$ & 0.20 & 0.022 & 0.090 & $0.01(0.007-0.011)$ \\
NTG-VLDL (3) & $8.2(7.8-8.7)$ & 4.10 & 0.330 & 3.530 & $0.26(0.21-0.30)$ \\
NTG-VLDL remnants (3) & $7.5(7.2-7.9)$ & 5.93 & 0.230 & 1.160 & $0.15(0.11-0.16)$ \\
HTG-VLDL (4) & $4.8(3.4-5.5)$ & 1.99 & 0.310 & 2.280 & $0.20(0.15-0.24)$ \\
HTG-VLDL remnants (6) & $4.5(4.2-5.1)$ & 2.77 & 0.230 & 1.220 & $0.19(0.15-0.25)$ \\
LDL (4) & $2.5(1.0-3.8)$ & 2.39 & - & 0.063 & $0.34(0.31-0.36)$ \\
HDL-E (2) & $0.04(0.038 / 0.044)$ & - & 0.029 & 0.001 & $0.003(0.002 / 0.004)$
\end{tabular}

* Number in parentheses indicates number of binding experiments.

Regulation of binding sites by preincubation of Hep G2 cells in lipoprotein-containing medium. When Hep G2 cells had not been preincubated in LPDS but were kept in $20 \%$ FCS, specific binding of LDL was completely abolished (Table III). The same result was obtained with cultured human fibroblasts. Affinity and binding sites for chylomicron remnants and HTG-VLDL were not affected by the preincubation with fetal calf serum, even after further addition of HDL-E and LDL at a final concentration of $200 \mathrm{mg}$ cholesterol/dl culture medium (Table III).

\section{Discussion}

High-affinity binding of chylomicrons, VLDL, LDL, and HDL$E$ to human hepatoma cells could be demonstrated in this study. The binding data were plotted according to Scatchard and yielded

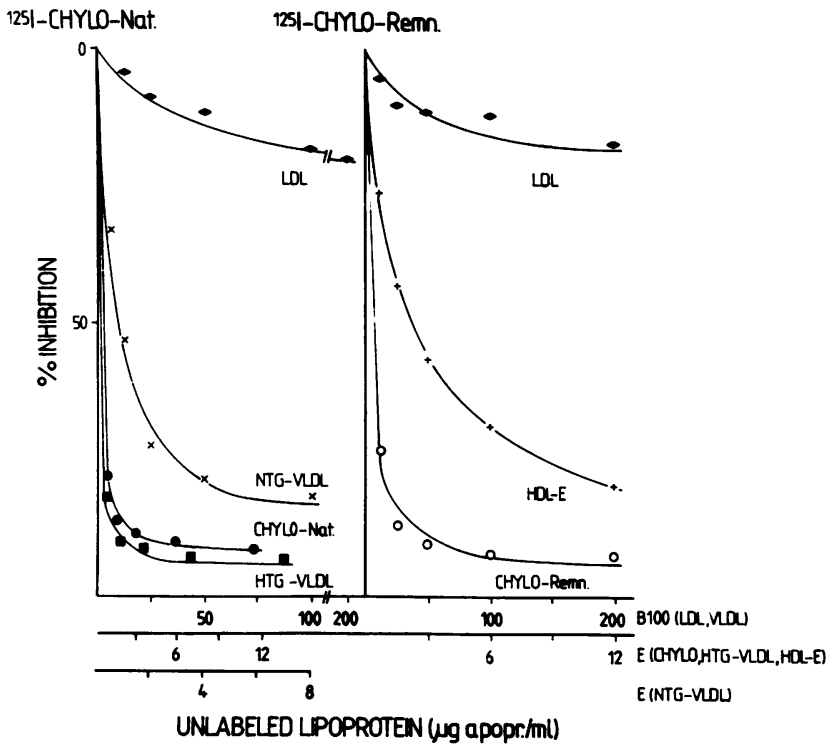

Figure 4. Competitive binding studies. (Left) Displacement of ${ }^{125} \mathrm{I}$-chylomicrons by unlabeled LDL $(\bullet)$, NTG-VLDL $(x)$, chylomicrons $(\bullet)$, and HTG-VLDL ( $\left(\right.$ ). (Right) Displacement of ${ }^{125}$ I-chylomicron remnants by unlabeled LDL ( $\bullet)$, HDLE-E (+), and chylomicron remnants (O). The apoprotein concentration of ${ }^{125} \mathrm{I}$-chylomicrons and chylomicron remnants in the incubation medium was $1 \mu \mathrm{g} / \mathrm{ml}$. The concentrations of Apo B and Apo E of the unlabeled lipoproteins are indicated on the abscissa. nonlinear curves for all lipoproteins tested. The curves could be resolved into two components, one component with a high affinity and one component with an extremely low affinity. The high-affinity component probably represents the high-affinity receptor binding. Linear Scatchard plots could not be demonstrated even under conditions of a 50-fold excess of unlabeled ligands in the binding assay. Therefore, the binding data were also calculated from total binding curves according to Mendel et al. (49). In all experiments the Scatchard transformation of total binding could be resolved in two exponentials. The calculated binding data were nearly identical when calculated from total or specific binding. The remnants of chylomicrons exhibited a considerable higher affinity than their native particles. Native and remnant chylomicrons showed some marked differences in their chemical composition. The remnant particles had a lower

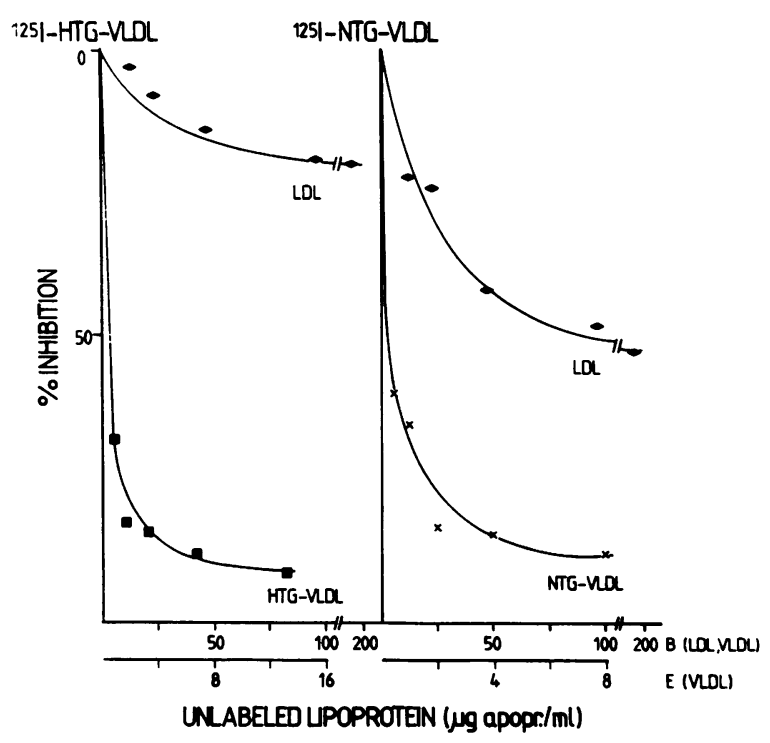

Figure 5. Competitive binding studies. (Left) Displacement of ${ }^{125} \mathrm{I}-$ HTG-VLDL by unlabeled LDL $(\bullet)$ and HTG-VLDL ( $(\bullet)$. (Right) Displacement of ${ }^{125}$ I-NTG-VLDL by unlabeled LDL $(\bullet)$ and NTG$\operatorname{VLDL}(x)$. Apoprotein concentration of ${ }^{125} \mathrm{I}-\mathrm{HTG}-\mathrm{VLDL}$ and ${ }^{125} \mathrm{I}-$ NTG-VLDL in the incubation medium was $1 \mu \mathrm{g} / \mathrm{ml}$. Concentrations of Apo B and Apo E of the unlabeled lipoproteins are indicated on the abscissa. 


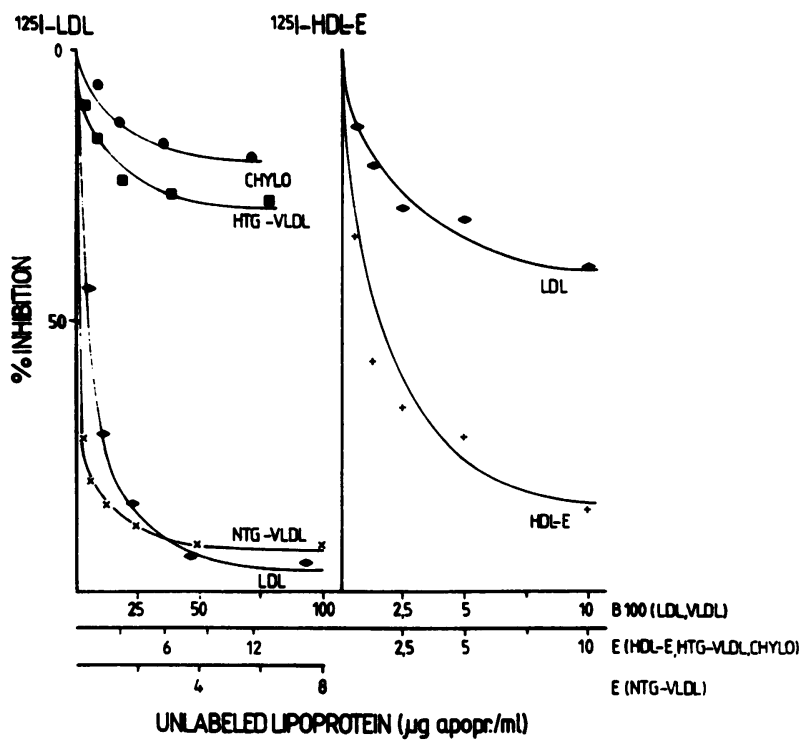

Figure 6. Competitive binding studies. (Left) Displacement of ${ }^{125} \mathrm{I}-$ LDL by unlabeled chylomicrons (๑), HTG-VLDL (๘), NTG-VLDL $(x)$, and LDL $(\bullet)$. (Right) Displacement of ${ }^{125}$ I-HDL-E by unlabeled LDL $(\bullet)$ and HDL-E (+). The apoprotein concentration in the incubation medium was $1 \mu \mathrm{g} / \mathrm{ml}$ for ${ }^{125} \mathrm{I}-\mathrm{LDL}$ and $0.1 \mu \mathrm{g} / \mathrm{ml}$ for ${ }^{125} \mathrm{I}-\mathrm{HDL}-\mathrm{E}$. The concentrations of Apo B and Apo E of the unlabeled lipoproteins are indicated on the abscissa.

content of triglycerides and Apo $\mathrm{C}$ and a higher content of Apo B. No significant difference could be observed for Apo E (Table I).

Although not directly determined, it must be assumed that the size of the particles has decreased after lipolysis. Therefore, several factors can be responsible for the increase of the binding affinity. Because Apo B 48 is not recognized by receptors on liver membranes (52), chylomicrons and their remnants are bound by Apo E. For VLDL it could be demonstrated that the conformation of the apoproteins is responsible for the recognition by the receptors $(53,54)$. After lipolysis of chylomicrons, Apo $E$ was not enriched in the remnants, but a significant decrease in Apo C content was observed. Shelburne et al. (55) investigated the role of Apo C III for the binding of Apo E containing lymph chylomicrons and triglyceride emulsions in liver perfusion studies. They found a pronounced inhibitory effect of Apo C III on hepatic removal of these lipoproteins. Windler et al. found an inhibitory effect of $\mathrm{C}$ apolipoproteins on the uptake of triglyceride-rich lipoproteins by perfused rat liver (56). The inhibitory effect of Apo $C$ could not be abolished by the addition of Apo $\mathrm{E}$ and, therefore, seems to be independent from the Apo E:C ratio. This was also confirmed by studies of Borensztajn et al.

Table III. Regulation of Binding by Lipoproteins in Preincubation Medium

\begin{tabular}{llll}
\hline Ligand & Preincubation medium & $K_{d}$ & $B_{\max }$ \\
\hline & & $\mu g / m l$ & $\begin{array}{l}\mu g \text { apoprotein } / m g \\
\text { cell protein }\end{array}$ \\
Chylomicrons & LPDS & 3.3 & 0.24 \\
Chylomicrons & FCS + LDL + HDL-E & 3.5 & 0.26 \\
HTG-VLDL & LPDS & 4.9 & 0.17 \\
HTG-VLDL & VCS + LDL + HDL-E & 4.7 & 0.20 \\
LDL & LPDS & 1.8 & 0.34 \\
LDL & FCS + LDL + HDL-E & No binding \\
\hline
\end{tabular}

(57). Therefore, the higher affinity of chylomicron remnants could be explained by the decrease in their Apo $\mathrm{C}$ concentration. A decrease of Apo $C$ concentration was also observed after lipolysis of VLDL. The binding affinity of VLDL remnants, however, was only slightly higher than that of native VLDL. The increase in the affinity probably depends on more than a single factor. From our studies it can not be decided which factors are responsible for the increase in the binding affinity after lipolysis of the triglyceride-rich particles.

Several studies have been performed to assess the specificity of the binding of various lipoproteins to hepatic receptors $(9$, $17,18,22)$. From these studies the existence of two distinct lipoprotein receptors on human liver cells seems to be established. There is general agreement that chylomicron remnants preferentially bind to the Apo $\mathrm{E}$ receptor and LDL to the $\mathrm{B} / \mathrm{E}$ receptor. The binding of VLDL particles, however, is not yet elucidated in detail. When the results of our experiments are interpreted in terms of two distinct lipoprotein receptors, chylomicrons and their remnants are bound by the $E$ receptor and LDL are bound by the B/E receptor, as already stated in other studies. Large HTG-VLDL preferentially bind to the E receptor because HTG-VLDL are as potent as chylomicrons in competing for receptor binding. As shown in Fig. 6, high concentrations of HTG-VLDL were also able to displace Apo E-free LDL from the receptor binding, although much less than NTG-VLDL. An explanation for this observation might be that HTG-VLDL are not completely homogenous and contain some particles which bind to the B/E receptor. The major fraction of HTG-VLDL, however, binds to the $\mathrm{E}$ receptor. This assumption is also supported by the finding that HTG-VLDL were bound to Hep G2 cells after down-regulation of the $\mathrm{B} / \mathrm{E}$ receptors. The observation that NTG-VLDL are able to displace chylomicrons and LDL suggests that NTG-VLDL are bound to both receptors. Further evidence for this hypothesis is derived from the observation that LDL displaces NTG-VLDL from receptor-binding but can not significantly inhibit receptor binding of HTG-VLDL even at high concentrations (Fig. 5). The observation that NTG-VLDL are bound by the $B / E$ receptor is in agreement with recent studies $(58,59)$. It has been found that Apo B and Apo E play a different role in receptor binding of VLDL of varying relative size. Apo E seems to be responsible for recognition of the larger HTGVLDL whereas Apo B is of increasing importance for receptor binding as the particles decrease in size $(53,54)$. These results, however, have been obtained with fibroblasts that exhibit only $B, E$ receptors. In our studies only NTG-VLDL were recognized by the B,E receptor of Hep G2 cells. Therefore B,E receptors of liver cells might differ from those of fibroblasts as already suggested by others (30). There also seems to be a difference in the metabolic fate of HTG-VLDL and NTG-VLDL. HTG-VLDL are primarily removed from the circulation whereas the smaller NTG-VLDL are largely converted to IDL and LDL (60). The recognition of these particles by different receptors might be important for their metabolic fate.

It must be emphasized that it is essential that LDL preparations used for displacement experiments are free of Apo E. In several experiments we could observe that Apo E in LDL preparations enables lipoproteins in the LDL density fraction to displace chylomicrons from their receptor binding. In our hands Apo $\mathrm{E}$ was always demonstrable in considerable concentrations in all LDL fractions prepared by conventional methods as ultracentrifugation and subsequent gel filtration. Apo E-free LDL could only be prepared by removal of Apo E with Apo E antibodies as described in Methods. 
It has already been pointed out above that binding affinity, specificity, and competitiveness of the various lipoprotein fractions are due to complex interactions between various apoproteins and the lipid composition of lipoprotein particles and receptor. Therefore, it should be stated that the binding data of this study are also compatible with the assumption of only one single hepatic receptor whose activity is affected by the complex apoprotein and lipid interactions.

An example for this alternative hypothesis is the finding of Koo et al. (61) that $\beta$-VLDL and LDL are bound by one single receptor, identified as an unusual $B / E$ (LDL) receptor on mouse peritoneal macrophages. LDL are bound by this receptor with a considerable lower affinity than $\beta$-VLDL and therefore a 1,000fold excess of LDL was necessary to achieve complete inhibition of $\beta$-VLDL binding to mouse macrophages. This result provided strong evidence against the existence of a unique $\beta$-VLDL receptor on macrophages as previously postulated $(62,63)$. A similar conclusion might also apply for the competitiveness between LDL and HDL-E. In our experiments an 50\% inhibition of HDL-E binding was achieved by a 100 -fold excess of unlabeled LDL apoprotein (Fig. 6). This finding is compatible with the assumption that HDL-E is bound not only by the LDL receptor but also by the remnant receptor. However, because HDL-E is bound with a considerable higher affinity to the hepatic cells than LDL, the possibility that the binding of HDL-E may be completely suppressed in the presence of an extremely high excess of LDL cannot be excluded. This would mean that HDL-E is bound only to the $\mathrm{B} / \mathrm{E}$ (LDL) receptor as shown for $\beta$-VLDL on mouse macrophages by Koo et al. (61). However, the observation in our study that HDL-E is capable of displacing chylomicron remnants from their receptor binding is an argument against this hypothesis.

Controversial results are reported concerning the requirement of $\mathrm{Ca}^{2+}$ for the receptor binding of LDL to liver cells (9, 23, 24, 30-34). Our results with Apo E-free LDL indicate that the binding of $\mathrm{LDL}$ to the $\mathrm{B} / \mathrm{E}$ receptor is $\mathrm{Ca}^{2+}$-dependent, whereas the binding of chylomicron remnants and HTGL-VLDL to the $\mathrm{E}$ receptor is not $\mathrm{Ca}^{2+}$-dependent. The presence of Apo $E$ in LDL preparations might explain the observations from other studies that hepatic LDL receptor binding was only partially blocked by EDTA $(30,32)$.

After preincubation of the Hep G2 cells with lipoprotein containing medium, binding of chylomicrons and HTG-VLDL was not suppressed, whereas the binding of LDL was abolished as already described by others (23). This is a strong argument for the existence of two receptors that are regulated differently. This result is consistent with the model that chylomicrons are rapidly cleared from the plasma, and thus cholesterol absorbed from the gut is taken up primarily by the liver, independent of cholesterol concentration in liver cells.

\section{Acknowledgments}

The technical assistance of Miss C. Garstenauer, Miss E. Meisl, and Miss H. Talman is gratefully acknowledged. We wish to thank Dr. M. Paulweber for the mathematical calculations.

This work was supported in part by the Österreich Fonds zur Förderung der Wissenschaftlichen Forschung, Project No. 5891.

\section{References}

1. Dietschy, J. M., and J. D. Wilson. 1986. Cholesterol synthesis in the squirrel monkey: relative rates of synthesis in various tissues and mechanisms of control. J. Clin. Invest. 47:166-174.
2. Radding, C. M., and D. Steinberg. 1960. Studies on the synthesis and secretion of serum lipoproteins by rat liver slices. J. Clin. Invest. 39: 1560-1569.

3. Abell, L. L., E. H. Mosbach, and F. E. Kendall. 1956. Cholesterol metabolism in the dog. J. Biol. Chem. 220:527-536.

4. Eriksson, S. 1957. Biliary excretion of bile acids and cholesterol in bile fistula rats. Bile acids and steroids. Proc. Soc. Exp. Biol. Med. 94: 578-582.

5. Goldstein, J. L., and M. S. Brown. 1974. Binding and degradation of low density lipoprotein by cultured human fibroblasts. Comparison of cells from a normal subject and from a patient with familial hypercholesterolemia. J. Biol. Chem. 249:5153-5162.

6. Goldstein, J. L., and M. S. Brown. 1957. Lipoprotein receptors, cholesterol metabolism and atherosclerosis. Arch. Pathol. 99:181-184.

7. Ho, Y. K., M. S. Brown, D. W. Bilheimer, and J. L. Goldstein. 1976. Regulation of low density lipoprotein receptor activity in freshly isolated human lymphocytes. J. Clin. Invest. 58:1465-1474.

8. Stein, O., and Y. Stein. 1976. High density lipoproteins reduce the uptake of low density lipoproteins by human endothelial cells in culture. Biochim. Biophys. Acta. 431:363-368.

9. Mahley, R. W., D. Y. Hui, T. L. Innerarity, and K. H. Weisgraber. 1981. Two independent lipoprotein receptors on hepatic membranes of dog, swine, and man. Apo-B,E and apo-E receptors. J. Clin. Invest. 68: 1197-1206.

10. Goldstein, J. L., and M. S. Brown. 1977. The low-density lipoprotein pathway and its relation to atherosclerosis. Annu. Rev. Biochem. 46:897-930.

11. Pitas, R. E., T. L. Innerarity, K. S. Arnold, and R. W. Mahley. 1979. Rate and equilibrium constants for binding of apo-E HDL $\mathrm{H}_{c}$ (a cholesterol-induced lipoprotein) and low density lipoproteins to human fibroblasts: evidence for multiple receptor binding of apo-E HDL $\mathrm{H}_{\mathrm{c}}$. Proc. Natl. Acad. Sci. USA. 76:2311-2315.

12. Eisenberg, S., and R. I. Levy. 1975. Lipoprotein metabolism. Adv. Lipid Res. 13:1-89.

13. Sherrill, B. C., T. L. Innerarity, and R. W. Mahley. 1980. Rapid hepatic clearance of the canine lipoproteins containing only the $\mathrm{E}$ apoprotein by a high affinity receptor. Identity with the chylomicron remnant transport process. J. Biol. Chem. 255:1804-1807.

14. Sherrill, B. C., and J. M. Dietschy. 1978. Characterization of the sinusoidal transport process responsible for the uptake of chylomicrons by the liver. J. Biol. Chem. 253:1859-1867.

15. Windler, E., Y.-S. Chao, and R. J. Havel. 1980. Determinants of hepatic uptake of triglyceride-rich lipoproteins and their remnants in the rat. J. Biol. Chem. 255:5475-5480.

16. Hui, D. Y., T. L. Innerarity, and R. W. Mahley. 1981. Lipoprotein binding to canine hepatic membranes. J. Biol. Chem. 256:5646-5655.

17. Hoeg, J. M., S. J. Demosky, Jr., R. J. Gregg, E. J. Schaefer, and H. B. Brewer, Jr. 1985. Distinct hepatic receptors for low density lipoprotein and apolipoprotein E in humans. Science (Wash. DC). 227:759761.

18. Dashti, N., and G. Wolfbauer. 1986. Studies on the binding and degradation of human very-low-density lipoproteins by human hepatoma cell line Hep G2. Biochim. Biophys. Acta. 875:473-486.

19. Fredrickson, D. S., J. L. Goldstein, and M. S. Brown. 1978. Metabolic Basis of Inherited Disease. J. B. Stanbury, J. B. Wyngaarden, and D. S. Fredrickson, editors. McGraw-Hill Book Co., New York. 4th ed. 604-655.

20. Kita, T., J. L. Goldstein, M. S. Brown, Y. Watanabe, C. A. Hornick, and R. J. Havel. 1982. Hepatic uptake of chylomicron remnants in WHHL rabbits: a mechanism genetically distinct from the low density lipoprotein receptor. Proc. Natl. Acad. Sci. USA 79:3623-3627.

21. Brown, M. S., and J. L. Goldstein. 1983. Lipoprotein receptors in the liver. J. Clin. Invest. 72:743-747.

22. Hui, D. Y., W. J. Brecht, E. A. Hall, G. Friedman, T. L. Innerarity, and R. W. Mahley. 1986. Isolation and characterization of the apolipoprotein E receptor from canine and human liver. J. Biol. Chem. 261: $4256-4267$.

23. Havekes, L., V. Van Hinsbergh, H. J. Kempen, and J. Emeis. 
1983. The metabolism in vitro of human low-density lipoprotein by the human hepatoma cell line Hep G2. Biochem. J. 214:951-958.

24. Wu, G. Y., C. H. Wu, V. A. Rifici, and R. J. Stockert. 1984. Activity and regulation of low density lipoprotein receptors in a human hepatoblastoma cell line. Hepatology (Baltimore). 4:1190-1194.

25. Dashti, N., G. Wolfbauer, E. Koren, B. Knowles, and P. Alaupovic. 1984. Catabolism of human low density lipoproteins by human hepatoma cell line HepG2. Biochim. Biophys. Acta. 794:373-384.

26. Havekes, L. M., D. Schouten, E. C. M. de Wit, L. H. Cohen, M. Griffioen, V. W. M. van Hinsbergh, and H. M. G. Princen. 1986. Stimulation of the LDL receptor activity in the human hepatoma cell line Hep $\mathbf{G} 2$ by high-density serum fractions. Biochim. Biophys. Acta. 875: 236-246.

27. Hoeg, J. M., S. B. Edge, S. J. Demosky, Jr., T. E. Starzl, T. Triche, R. E. Gregg, and H. B. Brewer, Jr. 1968. Metabolism of low-density lipoproteins by cultured hepatocytes from normal and homozygous familial hypercholesterolemic subjects. Biochim. Biophys. Acta. 876:646657.

28. Kovanen, P. T., D. W. Bilheimer, J. L. Goldstein, J. J. Jaramillo, and M. S. Brown. 1981. Regulatory role for hepatic low density lipoprotein receptors in vivo in the dog. Proc. Natl. Acad. Sci. USA. 78: 1194-1198.

29. Angelin, B., C. A. Raviola, T. L. Innerarity, and R. W. Mahley. 1983. Regulation of hepatic lipoprotein receptors in the dog. J. Clin. Invest. 71:816-831.

30. Hoeg, J. M., S. J. Demosky, Jr., K. J. Lackner, J. C. Osborne, Jr., C. Oliver, and H. B. Brewer, Jr. 1986. The expressed human hepatic receptor for low-density lipoproteins differs from the fibroblast lipoprotein receptor. Biochim. Biophys. Acta. 876:13-21.

31. Hoeg, J. M., S. J. Demosky, Jr., E. J. Schaefer, T. E. Starzl, and H. B. Brewer, Jr. 1984. Characterization of hepatic low density lipoprotein binding and cholesterol metabolism in normal and homozygous familial hypercholesterolemic subjects. J. Clin. Invest. 73:429-436.

32. Harders-Spengel, K., C. B. Wood, G. R. Thompson, N. B. Myant, and A. K. Soutar. 1982. Difference in saturable binding of low density lipoprotein to liver membranes from normocholesterolemic subjects and patients with heterozygous familial hypercholesterolemia. Proc. Natl. Acad. Sci. USA. 79:6355-6359.

33. Floren, C.-H. 1984. Binding of apolipoprotein E-rich remnant lipoproteins to human liver membranes. Scand. J. Gastroenterol. 19: 473-479.

34. Floren, C.-H. 1985. Hepatic binding of triglyceride-rich lipoproteins in humans. Scand. J. Clin. Lab. Invest. 45:531-537.

35. Bengtsson, G., and T. Olivecrona. 1977. Isolation of lipoprotein lipase from bovine milk. Biochem. J. 167:109-119.

36. Krauss, R. M., H. G. Windmüller, R. E. Levy, and D. S. Fredrickson. 1973. Selective measurement of two different triglyceride lipase activities in rat post-heparin plasma. J. Lipid Res. 14:286-295.

37. Bouthillier, D., C. F. Sing, and J. Davignon. 1983. Apolipoprotein E phenotyping with a single gel method: application to the study of informative matings. J. Lipid Res. 24:1060-1069.

38. Gustafson, A., P. Alaupovic, and R. H. Furman. 1965. Studies of the composition and structure of serum lipoproteins: isolation, purification, and characterization of very low density lipoproteins of human serum. Biochemistry. 4:596-605.

39. Laemmli, U. K. 1970. Cleavage of structural proteins during the assembly of the head of bacteriophage T4. Nature (Lond.). 227:680-685.

40. Havel, R. J., H. A. Eder, and H. J. Bragdon. 1955. The distribution and chemical composition of ultracentrifugally separated lipoproteins in human serum. J. Clin. Invest. 43:1345-1353.

41. Zechner, R., R. Moser, and G. M. Kostner. 1986. Isolation of pure LpB from human serum. J. Lipid Res. 27:681-686.

42. Stokke, K. T., and K. R. Norum. 1971. Determination of lecithin: cholesterol acyl transferase in human blood plasma. Scand. J. Clin. Lab. Invest. 27:21-27.

43. Kostner, G., and A. Holasek. 1970. Isolation of human serum low density lipoproteins with the aid of an immune-specific adsorber. Lipids. 5:501-504.

44. McFarlane, A. S. 1958. Efficient trace-labelling of proteins with iodine. Nature (Lond.). 182:53.

45. Bilheimer, D. W., S. Eisenberg, and R. I. Levy. 1972. The metabolism of very low density lipoprotein proteins. I. Preliminary in vitro and in vivo observations. Biochim. Biophys. Acta. 260:212-221.

46. Krempler, F., G. M. Kostner, A. Roscher, F. Haslauer, K. Bolzano, and F. Sandhofer. 1983. Studies on the role of specific cell surface receptors in the removal of lipoprotein(a) in man. J. Clin. Invest. 71:14311441.

47. Scatchard, G. 1949. The attraction of proteins for small molecules and ions. Ann. NY Acad. Sci. 51:660-672.

48. Munson, P. J., and D. Rodbard. 1980. Ligand: a versatile computerized approach for characterization of ligand-binding systems. Anal. Biochem. 107:220-239.

49. Mendel, C. M., and D. B. Mendel. 1985. Non-specific binding. Biochem. J. 228:269-272.

50. Lowry, O. H., N. J. Rosebrough, A. L. Farr, and R. J. Randall. 1951. Protein measurement with the Folin phenol reagent. J. Biol. Chem. 193:265-275.

51. Eggstein, M., and F. H. Kreutz. 1966. Eine neue bestimmung der neutralfette im blutserum und gewebe. I. Mitteilung. Prinzip, durchführung und besprechung der methode. Klin. Wochenschr. 44:262-265.

52. Hui, D. Y., T. L. Innerarity, R. W. Milne, Y. L. Marcel, and R. W. Mahley. 1984. Binding of chylomicron remnants and $\beta$-very low density lipoproteins to hepatic and extrahepatic lipoprotein receptors. J. Biol. Chem. 259:15060-15068.

53. Bradley, W. A., S.-L. C. Hwang, J. B. Karlin, A. H. Y. Lin, S. C. Prasad, A. M. Gotto, Jr., and S. H. Gianturco. 1984. Low-density lipoprotein receptor binding determinants switch from apolipoprotein E to apolipoprotein B during conversion of hypertriglyceridemic verylow-density lipoprotein to low-density lipoproteins. J. Biol. Chem. 259: 14728-14735.

54. Krul, E. S., M. J. Tikkanen, T. G. Cole, J. M. Davie, and G. Schonfeld. 1985. Roles of apolipoprotein $B$ and $E$ in the cellular binding of very low density lipoproteins. J. Clin. Invest. 75:361-369.

55. Shelburne, F., J. Hanks, W. Meyers, and S. Quarfordt. 1980. Effect of apoproteins on hepatic uptake of triglyceride emulsions in the rat. J. Clin. Invest. 65:652-658.

56. Windler, E., and R. J. Havel. 1985. Inhibitory effect of C apolipoproteins from rats and humans on the uptake of triglyceride-rich lipoproteins and their remnants by the perfused rat liver. J. Lipid Res. 26:556-565.

57. Borensztajn, J., and T. J. Kotlar. 1984. Liver uptake of chylomicron remnants with high and low apoprotein E:C ratio. Proc. Natl. Acad. Sci. USA. 81:5863-5866.

58. Windler, E., P. T. Kovanen, Y.-S. Chao, M. S. Brown, R. J. Havel, and J. L. Goldstein. 1980. The estradiol-stimulated lipoprotein receptor of rat liver. J. Biol. Chem. 255:10464-10471.

59. Tamai, T., W. Patsch, D. Lock, and G. Schonfeld. 1983. Receptors for homologous plasma lipoproteins on a rat hepatoma cell line. J. Lipid Res. 24:1568-1577.

60. Packard, C. J., A. Munro, A. R. Lorimer, A. M. Gotto, Jr., and J. Shepherd. 1984. Metabolism of apolipoprotein B in large triglyceriderich very low density lipoproteins of normal and hypertriglyceridemic subjects. J. Clin. Invest. 74:2178-2192.

61. Koo, C., M. E. Wernette-Hammond, and T. L. Innerarity. 1986. Uptake of canine $\beta$-very low density lipoproteins by mouse peritoneal macrophages is mediated by a low density lipoprotein receptor. J. Biol. Chem. 261:11194-11201.

62. Mahley, R. W. 1983. The development of accelerated atherosclerosis. Concepts derived from cell biology and animal model studies. Arch. Pathol. Lab. Med. 107:393-398.

63. Brown, M. S., and J. L. Goldstein. 1982. Lipoprotein metabolism in the macrophage: implication for cholesterol deposition in atherosclerosis. Annu. Rev. Biochem. 52:223-261. 